\title{
Kina gør sig til centrum for det asiatiske hjul Thomas Høy Davidsen
}

\section{De næste ti år bliver kritiske, for her skal ikke kun magtbalancen, men også tillidsbalancen mellem Kina, Japan, Indien - og USA formes}

Den prominente amerikanske udenrigskorrespondent Bradley K. Martin, der har over tredive års erfaring i regionen, fortalte mig engang, at hvis USA fra 2020 ikke længere kan omringe Kina militært og diplomatisk, vil Kina have opfyldt en af sine mest underspillede, men vigtigste udenrigspolitiske ambitioner for det tidlige 21. århundrede.

Det ville være naivt at tro, forklarede han, at den internationale orden i Asien og Stillehavet vil forblive uændret i takt med, at Kina indfrir sit enorme $\varnothing$ konomiske potentiale. Og da Kina vel er klar over, at kun USA i princippet kan sætte en stopper for dets vækstmirakel, er det i Kinas interesse at udvande USA's og Vestens indflydelse i Asien så meget som muligt.

Beslutningsprocesserne i Kinas politiske elite er notorisk uigennemsigtige, men ud fra den udenrigspo- litik, som den kinesiske ledelse har ført gennem det sidste årti, er det klart, at landet aktivt søger at manifestere sig solidt i sin geografiske periferi. Denne udvidelse af kinesisk indflydelse har haft og vil fortsat have store konsekvenser for både Vesten og Asien.

Bedre relationer mellem Kina og regionerne i den kinesiske periferi er absolut ønskelig set fra en kinesisk strategs synspunkt, for Kina var ved den kolde krigs afslutning omringet af USA's indflydelsessfære. Ud for Kinas sydlige kyst ligger Taiwan som et solidt amerikansk anker, og i nord er Japan og Sydkorea officielt USA's allierede - og begge er i besiddelse af et avanceret forsvar mens USA efter den kolde krig derud over hurtigt etablerede en vis indflydelse i Mongoliet, Kinas gamle provins fra Qing Dynastiet.

Rusland dominerer Sibirien og 
kan i teorien true hele Kinas lange, nordlige grænseområde, der er præget af fattigdom og ustabilitet. I Centralasien er den russiske indflydelse også stor, og oveni har NATO med USA i spidsen markeret sig i området som en konsekvens af krigen i Afghanistan. Længere mod syd ligger Indien, som Kina stadig har en uløst grænsestrid med fra landenes krig tilbage i 1962, og Indiens økonomiske udvikling kunne på sigt virke som en modvægt til Kina og dermed true dets interesser. Cirklen sluttes i Sydøstasien, der nu domineres af et amerikansk-allieret Thailand og af Malaysia og Indonesien, der efter den kolde krig i årtier har lagt sig tæt op ad USA.

\section{Behovet for dominans}

Det ville dog være unødigt paranoidt at konkludere, at Kina med sit hastigt voksende militærbudget er ved at opruste sig til en væbnet konflikt, der skal udligne ubalancen. Kinas voksende militære omkostninger er en naturlig konsekvens af landets voksende politiske og økonomiske indflydelse, men naturligvis kan en øget militær styrke bruges til andet end selvforsvar. Modsat andre af Asiens industrialiserede lande som Japan og Sydkorea har Kinas militær på en langt mere udadvendt facon haft til opgave at forsvare og promovere Kinas udenrigspolitiske interesser, som vil vokse i takt med landets økonomiske indflydelse.
Kinas oprustning er bekymrende for nogle, men der er historisk præcedens for både fred og ufred i forbindelse med en ny regional stormagts fødsel.

Kinas oprustning kan sammenlignes med både Japans og USA's i 1800-tallet, hvor deres militær også voksede i takt med, at begge disse lande udviklede sig til stormagter. Ligesom Kina i dag førte begge landes oprustning til spændinger mellem dem og deres naboer, og ligesom Kina i dag anså både USA og Japan det alligevel for bydende nødvendigt at kunne dominere de af deres geografiske naboområder, der var væsentlige for nationens sikkerhed og den økonomiske vækst.

Det var netop på denne baggrund, at den amerikanske præsident James Monroe i 1823 formulerede den berømte Monroe-doktrin, hvori han erklærede, at USA ikke kunne acceptere europæisk militær tilstedeværelse noget sted i Sydamerika, idet en ikke-amerikansk dominans af dette kontinent ville 'indespærre' USA.

På lignende vis ræsonnerede det kejserlige Japan allerede tidligt i sin industrialiseringsperiode på tragisk vis, at det måtte annektere Korea for med Japans første premierminister Ito Hirobumis ord lød argumentet allerede sidst i 1800-tallet, at en russisk eller kinesisk dominans af den koreanske halvø ville repræsentere "en dolk, der pegede direkte mod hjertet af Japan". 
Geografi dikterer både økonomi og storpolitik, og disse to blandes ofte sammen.

\section{Kinas Monroe-doktrin}

Kina forsøger nu gennem økonomisk investering og diplomatisk snilde - begge bakket op af den førnævnte heftige militære oprustning - at skabe sig en art 'Monroe-doktrin', og landet har derfor i over ti år støt arbejdet på at reorganisere Øst-, Central- og Sydøstasiens netværk af alliancer, organisationer og handelspartnere i et forsøg på at integrere de omkringliggende lande i et nyt økonomisk og politisk system, der har Kina som centrum.

Den kinesiske militæropbygning er dermed hverken kalkuleret aggression eller regelret selvforsvar, men en naturlig konsekvens af landets nyvundne status som stormagt også selvom dette, som både USA's og Japans historie har vist, kan give anledning til farlige spændinger. Det er nemlig et ambitiøst projekt, Kina har påtaget sig, som det ikke kan føre ud i livet uden samtidig at træde andre af verdens stormagter over tæerne, først og fremmest USA.

"Der foregår i dag en rivalisering mellem de asiatiske stormagter Kina, Japan og Indien - og USA," fortæller tidligere chefredaktør for The Economist, Bill Emmott: "Denne rivalisering kan blive positiv, som den vi ser mellem de europæiske $ø$ konomier, der konkurrerer venska- beligt, eller den kan blive destruktiv. De næste ti år bliver kritiske, for det er ikke blot her magtbalancen, men også tillidsbalancen mellem disse nationer vil formes."

Mest følelsesladet i den kinesiske udenrigspolitik er således den fortsatte debat om Taiwan, men der er under de nationalistiske udlægninger af Taiwan som den tabte provins også en klar strategisk interesse bag Kinas ønske om at besidde ølandet. Taiwan er nemlig geografisk set en naturlig forlængelse af det kinesiske fastland - indtil man skifter fokus, og øen pludselig bliver den øverste i den lange filippinske økæde eller den sidste af de japanske Ryukyu øer.

Taiwans centrale geografi gør derfor øen til et af de vigtigste knudepunkter i Stillehavet - næsten al Japans olieimport går op langs øens kyst - og kontrol med Taiwan ville klart forøge den kinesiske indflydelse i regionen.

Selvom Kinas økonomi er så stor, at den sagtens kan klare sig uden Taiwans meget mindre bruttonationalprodukt, er øens unikke økonomi alligevel ikke uden betydning Taiwan er så fundamental en del af den globale manufaktur- og højteknologiindustri, at næsten intet elektronisk udstyr i verden er foruden en taiwansk produceret komponent. Det gør øen til et af de vigtigste enkelte led i den globale økonomi, og det er næppe gået kinesiske strategers næse forbi. 
"I takt med at Kinas udvikling tager til i styrke, og landets agtelse i det internationale samfund vokser," skrev avisen People's Liberation Army Daily i 2007, "er det af stor vigtighed at skabe et forsvar, der svarer til Kinas indflydelse, som kan forsvare kinesiske interesser og underbygge Kinas internationale status."

\section{Frygt for Taiwan konflikt}

Det er denne overordnede filosofi, sammen med den mere konkrete frygt for en konflikt med USA om Taiwans uafhængighed, der ligger bag Kinas voldsomme investering i moderne militært isenkram, fra opgraderingen af landets ubådsstyrke og kampfly til udviklingen af skib-til-skib missiler og en flåde af hangarskibe.

Denne prioritering burde ikke komme som en overraskelse - igennem historien har nationer som USA, Japan, England, Frankrig, Spanien, Venedig og det gamle Athen bygget krigsflåder med det formål at kunne forsvare deres vidtstrakte $\varnothing$ konomiske interesser, og Kina er ingen undtagelse.

Der har derfor også blandt dele af den kinesiske militære og civile ledelse i de seneste år været tale om en tretrins udvidelse af yderpunkterne for Kinas maritime indflydelse, således at Kina langsomt vil kunne dominere mere og mere af Stillehavet: Den første udvidelse vil fungere som en halvcirkel, der løber fra Japan til Taiwan og Filippinerne, mens den næste trækkes fra den russiske $\varnothing$ Sakhalin ned gennem det sydvestlige Stillehav. Den sidste og største udvidelse planlægges at skulle gå fra Aleutian øerne ud for Alaska og helt til Antarktis.

Opfyldelsen af disse strategiske mål ligger langt ude i fremtiden, men tanken er i sig selv ikke irrationel. Kina sluger på grund af sin enorme vækst råstoffer med rekordfart, og disse råstoffer importeres næsten alle via det Indiske Ocean og Stillehavet. Ud over at være blevet en af de vigtigste handelspartnere for lande som Japan, Sydkorea, Australien og diverse sydøstasiatiske lande er den kinesiske handel med Sydamerika vokset fra 200 millioner dollars i 1975 til næsten 50 milliarder dollars i 2004, mens begge ender af Panamakanalen kontrolleres af et kinesisk firma. Og ligesom andre af historiens stormagter anser Kina det for bydende nødvendigt at kunne forsvare disse investeringer, også på trods af spændingerne med nabolandene.

Gennem et netværk af nødhjælp, diplomati og økonomisk investering - som eksempelvis Kinas opførelse af en sofistikeret satellitsporingsinstallation på stillehavsøen Kiribati er Kina samtidig ved at skabe sig et netværk af forbindelser hen over oceanets vidtstrakte øsamfund, der på sigt skal sikre den kinesiske indflydelse i regionen samtidig med, at den underminerer USA's tilstedeværelse. 
Det er ligeledes et problem set ud fra Kinas synspunkt, at Sydøstasien i de sidste tres år har været tæet knyttet til USA.

Det forsøger Kina nu at lave om på, både ved at involvere sig voldsomt i ASEAN for at udvande organisationens regionale indflydelse uden om Kina, men også ved at skabe, præcis som USA gjorde det under den kolde krig, et væld af bilaterale handelsaftaler med de enkelte sydøstasiatiske lande, der hurtigt kan gøre disse landes forhold til Kina stærkere end til hinanden, til ASEAN eller til Vesten og USA.

\section{Afhængighed af Kina}

Når der tilmed er så stor forskel i størrelse på Kina og de andre sydøstasiatiske lande, kan disse også hurtigt blive afhængige af at tilgodese Kina af frygt for at miste den nødvendige kinesiske investering.

"I det sidste årti er de kinesiske forbindelser i Sydøstasien og især Indonesien vokset dramatisk," fortæller den Pulitzer Pris-vindende journalist og specialist i området, Lewis M. Simons: "Kinesiske firmaer kommer til med Beijings pengepung i ryggen samtidig med, at de kinesiske diplomater også på græsrodsniveau har været meget dygtige til at skaffe sig indflydelse." Simons arbejder nu med amerikanske senatorer i et forsøg på at få det amerikanske udenrigspolitiske fokus flyttet tilbage til regionen.
Nogle gange er sådanne investeringer direkte politiske: I 2007 tilbød Verdensbanken, Asian Development Bank og diverse vestlige lande i fællesskab Cambodja en økonomisk nødhjælpspakke på svimlende 600 millioner dollars, næsten hele landets statsbudget, mod at Cambodjas regering hurtigst muligt tog en række konkrete skridt frem mod at overholde menneskerettighederne.

Kina tilbød prompte præcis den samme sum - men uden lignende krav, og Cambodja takkede pænt nej til Vesten. Det er yderligere uheldigt, at den kinesiske investering ofte sker på bekostning af enten miljøet - som på indonesiske Borneo og Kalimantan, hvor den kinesiske tømmerindustri nu har fældet over halvdelen af øernes regnskove - eller netop menneskerettighederne, som det sås i Cambodja.

Endnu et eksempel er Burma, hvor det internationale pres på regeringen for demokratisering, ophør af etnisk forfølgelse og overholdelse af menneskerettighederne for længst er blevet overhalet af en massiv kinesisk investering.

"Japanske firmaer taber i dag ofte til de kinesiske i Sydøstasien, fordi den kinesiske regering lover at finansiere enorme infrastrukturprojekter for udviklingslandene, hvis disses regeringer giver Kinas statsejede firmaer de lukrative kontrakter," får jeg at vide af Shinji Nishio, bestyrelsesformand for JX Group, Japans største olie- og energifirma: 
"Mine kollegaer i japansk industri og jeg lobbyer nu af nødvendighed den japanske regering for at gøre det samme."

\section{Malacca som flaskehals}

Interessen i Sydøstasien er også strategisk, da et sårbart punkt for Kinas Stillehavshandel er Malaccastrædet mellem Singapore og Indonesien, der ved sit smalleste punkt ikke er stort bredere end en kilometer. Især Japans og Kinas olieimporter er dybt afhængige af denne flaskehals.

Det gør for eksempel Burma interessant for Kina, ikke blot fordi Kina ønsker at få adgang til landets olie- og gasreserver, men også fordi Burmas havne repræsenterer et alternativ til Malaccastrædet, idet den kinesiske import ville kunne transporteres via Burma direkte til Kinas Yunnan-provins. Kina har derfor også været involveret i forhandlinger med Thailand om et af Asiens største byggeprojekter nogensinde en enorm kanal, der skal gennemskære Thailands Kra Isthmus, igen så Kinas import har et alternativ til Malaccas flaskehals.

USA's tilstedeværelse i Thailand er ellers en af dens stærkeste i Asien. En af landets største ambassader ligger i Bangkok, og Thailand har været en af USA's nøgleallierede siden Vietnam-krigen, men projekter som den omtalte kanal samt den hastigt voksende samhandel med Kina sår tvivl, om Thailand en dag venligt, men definitivt vender sig fra Uncle Sam.

Denne blanding af handel og mere eller mindre aggressivt diplomati kan ses i hele den kinesiske periferi - Kina er Australiens største aftager af uran, jern, mangan og naturgas, og i 2005 underskrev Australien som en kinesisk betingelse for yderligere samhandel ASEANs Treaty of Amity and Cooperation, en ikke-aggressionspagt, der stikker en kæp i hjulet på Australiens alliance med USA. Samtidig gør handlen det svært for Australien at kritisere selv Kinas alvorligste brud på menneskerettighederne.

Ligeledes har Kina finansieret udvidelsen af Pakistans Karakoram-motorvej til en værdi af 350 millioner dollars, så den nu løber tværs gennem Baluchistan-provinsen ned til kystbyen Gwadar, hvor Kina er ved at bygge en enorm havn og et olieraffinaderi.

Karakoram-motorvejen munder ud i den kinesiske Xinjiang-provins, og hele det kostbare projekt har igen til formål at skaffe især Kinas olieimport en vej uden om Malaccastrædet - med den konsekvens, at Kina nu har presset den pakistanske regering til at trække soldater væk fra grænseområderne langs Afghanistan og ned til Baluchistan for at holde orden der. Yderligere lovede Kina i 2010 desuden at hjælpe Pakistan med at opføre to atomreaktorer, meget mod Vestens og Indiens ønsker. 


\section{Køber i Nordkorea}

I nord har Kina opkøbt næsten samtlige af Nordkoreas miner og størstedelen af dets jernbanenetværk, og den nordkoreanske handel og nødhjælp har gjort det lille, lukkede land så afhængigt af Kina, at en koreansk genforening nu nærmest er utænkelig, uden at den foregår på Kinas betingelser.

Det sydlige Sibirien og Mongoliet er i de seneste ti år blevet oversvømmet af en mere eller mindre illegal strøm af kinesiske indvandrere - i snit 600.000 om året - der uofficielt har givet Beijing en enorm indflydelse og kontrol med områderne nord for den kinesiske grænse, idet det som oftest nu er kinesiske tilflyttere, der bosætter sig, investerer i og udvikler områderne.

Eksemplerne på asiatiske økonomiers voksende afhængighed af Kina står i kø, fra den måde Kina nu planter dele af sin rishøst i Filippinerne, så det selv kan bruge det ny- vundne land til motorveje og fabrikker, til hvordan Kina sammen med Rusland i 2009 pressede Kirgisistan til at afvise USA's ønske om fortsat at anvende Manas flyvebasen ved den kirgisiske hovedstad Bisjkek til brug for krigsindsatsen i Afghanistan. En ny aftale kom først i stand, efter at USA indvilligede $i$ at betale 60 millioner dollars om året eller tre gange den tidligere leje.

Hvis denne trend fortsætter, er det ikke urealistisk, at Beijing, gennem dygtig anvendelse af både globaliseringens økonomiske kræfter og sit stille, intense diplomati, bid for bid vil kunne realisere en form for Monroe-doktrin for Riget i Midten - et Kina, der som centrum for et asiatisk hjul trækker sine eger langt ud i kontinentets periferi.

Thomas Høy Davidsen er journalist med speciale i Japan og østasiatiske forhold. Bosat $i$ Tokyo og skriver for bl.a. Economist og Jyllands-Posten. 